\title{
AndHD
}

\section{Anonim Şirketlerde İç Yönerge ve İç Yönergenin Yönetim Kurulunun Sorumluluğuna Etkisi ${ }^{(*)}$}

\author{
Internal Directive in Joint Stock Companies and \\ the Impact of the Internal Directive to the Liability of the Board of Directors
}

\author{
Hasan KARSLIOĞLU \\ Doktor Öğretim Üyesi \\ İstanbul Teknik Üniversitesi \\ Issletme Fakültesi \\ İsletme Mühendisliği Bölümü
}

\section{Anahtar Kelimeler \\ Yetki Devri, \\ Sorumluluk, \\ İ̧̧ Yönerge, \\ Torba Kanun, \\ Hükümler Arası \\ Çelişki.}

\section{Keywords}

Delegation,

Liability,

Internal Directive,

Omnibus Bill,

Conflict Between

Provisions.
Öz

İç yönerge kavramı, anonim şirketlerde iki farklı durumda gündeme gelmektedir. Bunlardan biri genel kurul toplantı esaslarının düzenlendiği iç yönerge olup diğeri ise anonim şirketin yönetimine ilişkin iç yönergedir. Yönetime ilişkin iç yönerge bakımından anonim şirketlerde yönetim kurulunun haiz olduğu yetkileri usulüne uygun biçimde devredebilmesi, bu konuda esas sözleşmede bir hükmün yer alması ve bununla birlikte iç yönerge metninin bir yönetim kurulu kararı ile yürürlüğe girmesiyle mümkün olur. İç yönerge, özellikle taşıdığı işlev bakımından önem kazanmakta ve esasen sorumluluğun sınırlandırılması amacına hizmet etmektedir. Bu doğrultuda çalışmamızda anonim şirketlerde yönetim kurulu iç yönergesi bağlamında yetki devrinin kapsamı, devrin yasal şartları, devrin sorumluluk üzerindeki etkisi ile birlikte 6552 sayılı Kanun'un ilgili hükümleri inceleme konusu yapılmakta ve yeni düzenlemenin doğurduğu sonuçlara dair güncel tartışmalar ele alınmaktadır.

\begin{abstract}
The concept of internal directive comes to the fore in two different situations in joint-stock companies. One of them is the internal directive on the organization of the general assembly meeting principles, and the other is the internal directive on the management of the joint-stock company. In terms of the internal directive regarding management, in joint-stock companies, the board of directors can delegate its authorities duly, with a provision in the articles of association in this regard, and with this, the text of the internal directive to come into force by a decision of the board of directors. The internal directive gains importance, especially in terms of its function, and essentially serves the purpose of limiting liability. In this respect, in our study, the scope of the del egation of authority in the context of the internal directive of the board of directors in jointstock companies, the legal conditions of the delegation, the impact of the delegation on responsibility, as well as the relevant provisions of the Law No. 6552 are examined and current debates about the results of the new regulation are discussed.
\end{abstract}

(*) Araștırma Makalesi.

Hakem denetiminden geçmiştir.

Gönderim Tarihi : 30.11.2021, Makalenin Kabul Tarihi: 10.01.2022 


\section{GİRIS}

Türk Ticaret Kanunu'nun (TTK) 365'inci maddesi uyarınca anonim şirketler yönetim kurulu tarafindan yönetilir ve temsil edilir. Yönetim kurulunun yönetim ve temsil görevinden doğan sorumluluk da TTK'nın 553'üncü maddesi uyarınca yine yönetim kuruluna aittir. Ancak iç yönergeye göre atanan yöneticilerin/temsilcilerin, şirkete ya da üçüncü kişilere zarar vermesi halinde sorumluluk meselesinin tayininin sorumluluğu düzenleyen TTK m. 553/2 düzenlemesinin doğuracağ bağdaşmadığı hususunun ortaya koyulması bir gerekliliktir. Bu kapsamda, iç yönergenin yöneticilerin/temsilcilerin sorumluluğunun belirlenmesi noktasındaki etkisi son derece önemlidir. Bu hususların TTK' daki yönetim kurulunun sorumluluğuna dair hükümler ve yönetimin iç yönerge aracılığıyla devredilmesi hususundaki hükümler ile karşılaştırılarak incelenmesi gerektiği kanaatindeyiz.

Bu nedenle tüm bunlar inceleme konusu yapılmadan önce yönetim kavramının genel hatlarıla ele alınmasında fayda mütalaa etmekteyiz. TTK sistematiği bağlamında işlevsel olarak yönetim kavramı, şirketin faaliyet konusunun gerçekleştirilmesine yönelik her çeşit kararın alınması ve alınan kararların gerek şirketin iç işleyişinde gerekse dış ilişkilerde somutluk kazanmasını, dolayısıyla uygulanmasını ifade etmektedir ${ }^{1}$. Bu doğrultuda yönetim kavramının muhtevasını, her şeyden önce şirketin kısa ve/veya uzun vadeli hedefleri ve bu hedeflere ulaşma yolunda kullanılan araçlar oluşturmaktadır. Dolayısıyla yönetme kavramının, işletme stratejisi ile sıkı bir bağlılık içerisinde olduğunu ifade etmek mümkündür ${ }^{2}$. Anonim şirket yönetim kurulu, işletme stratejisi bakımından iki farklı işleviyle karşımıza çıkmaktadır. Kurul, bir taraftan şirketin yönetim organı olma özelliğini taşırken diğer taraftan da temsil organı sıfatıyla şirketin haklara ve borçlara ehil olmasını sağlamaktadır. Kural bu olmakla birlikte yönetim kurulunun yönetim hakkı ile temsil yetkisini bizzat kullanma zorunluluğu bulunmamaktadır $^{3}$. Zira kanun koyucu TTK' daki ilgili düzenlemelerle söz konusu hak ve yetkilerin devredilebilmesine imkân vermiştir. Böylelikle yönetim kurulunun gerektiğinde gözetim organına benzer şekilde çalışabileceği esnek bir sistem ihdas edilmiştir ${ }^{4}$ Bu kapsamda, yönetim kurul unun yetkilerini devredip etmediğine bakılmaksızın her durumda geniş yetkiyi haiz yasal bir organ olduğu ifade edilebilir.

Anonim şirketlerde yönetim kurulunun geniş yetkilere sahip olması, buna paralel olarak sorumluluğu da beraberinde getirmektedir. Kanun koyucu, şirket yönetimindeki kişilerin sınırsız karar alma yetkisi ile donatılmaması, bu kişilerin bağımsız olarak görevlerini icra edebilmesi ve yönetim kurulunun sorumluluğunun sınırlandırılmas $1^{5}$ gibi amaçlarla TTK'nın iki farklı hükmünde yönetimkurulu iç yönergesine dair kurallar ihdas etmiştir6. Doktrinde kabul edildiği üzere, TTK'nın yönetim kurulunun vazgeçilmez ve devredilmez yetkilerini düzenleyen 375' inci maddesinde bahse konu vazgeçilmez ve devredilmez yetkiler sınırlı sayı ilkesi (numerus clausus) uyarınca düzenlenmemiştir ${ }^{7}$. Konu bu kapsamda ele alındığında iç yönergeyle hangi yetkilerin devredilebileceği, iç yönergenin hazırlanması ve kapsamı, hazırlanan iç yönergenin yönetim kurulunun sorumluluğunu nasıl etkileyeceği gibi hususlar önem kazanmakta ve çalışmamızın odak noktasını oluşturmaktadır.

1 DEMIREL, Duygu: “Anonim Şirketlerde Yönetim Yetkisinin Devri”, Hacettepe Üniversitesi Hukuk Fakültesi Dergisi, 2017, Cilt 7, Sayı 2, s. 214; SENER, Oruç Hami: Ortaklıklar Hukuku Ders Kitabl, 4. Baskı, Seckin Yayıncılık, Ankara, 2019, s. 352; AYHAN, Rıza / ÇAĞLAR, Hayrettin / ÖZDAMAR, Mehmet: Şirketler Hukuku Genel Esaslar, 3. Baskı, Yetkin Yayınevi, Ankara, 2021, s. 307; MANAVGAT, Çağlar / ŞEHIRALI ÇELIK, Feyzan Hayal / KIRCA, İsmail: Anonim Şirketler Hukuku, Cilt 1, Banka ve Ticaret Hukuku Araştırma Enstitüsü Yayınları, Ankara, 2013, s. 528.

2 PULAȘLI, Hasan: Şirketler Hukuku Genel Esaslar, 7. Bask1, Adalet Yayınevi, Ankara, 2021, (Genel Esaslar), s. 410; ÖZER, Akif: "İşletmelerde Stratejinin Önemi Üzerine Değerlendirmeler", Uluslararası İktisadi ve İdari İncelemeler Dergisi, 2015, Cilt 1, Say1 14, s. 74.

3 TTK 367/1 Madde Gerekçesi; PULAŞLI, Hasan: Şirketler Hukuku Şerhi, Cilt 2, 3. Baskı, Adalet Yayınevi, Ankara, 2018, (Şerh), s. 1358.

4 TTK 367/1 Madde Gerekçesi.

5 TTK m 367 hükmünün gerekçesinde, devrin organsal işlevleri içermesi nedeniyle sorumluluk yönünden önemli sonuçlar doğuracağı belirtilmiştir. Aynı yönde ve devrin sorumluluğu sınırlaması yönünde bkz. ŞENER, s. 372.

6 TTK m. 367' de yönetim yetkisinin devri, TTK m 370/2'de ise temsil yetkisinin devri düzenlenmiştir.

7 HELVACl, Mehmet: "Yönetim Kurulunun Anonim Şirketi İdare ve Temsili, Özellikle Devredilemez Görev ve Yetkileri”, Bahçeşehir Üniversitesi Hukuk Fakültesi Dergisi, 2014, Cilt 9, Sayı 117-118, s. 128. 


\section{ANONIM ŞIRKETLERDE YÖNETIMIN ORGANIZASYONU VE YETKİ DEVRINIIN ANLAMI}

TTK'nın 365'inci maddesi gereğince, anonim şirketin yönetimi ve temsili ile yetkilendirilmiş yasal organ yönetim kuruludur. Kurul yetkilerini Kanun'dan almaktadır. Bu bağlamda yönetim kurulu hem şirketin işletme konusunu gerçekleştirmeye yönelik kararlar almakla, hem de diş ilişkide temsil yetkisini kullanarak şirketin hak ve borçlara ehil olmasını sağlamakla görevlidir.

Yönetim kurulu, anonim şirkette yetkileri itibari ile, şirket açısından "uygulayıcı" sıfatına sahip organ olarak hareket etmektedirs. Bunun yanında yönetim yetkisi, kural olarak yönetim kuruluna ait bir yetki olmakla birlikte bu yetki ancak esas sözleşmeye dayanılarak çıkartılan iç yönerge kapsamında yönetim kurulu üyelerinden birine veya birkaçına devredilebilir'. Zira TTK'nın benimsediği sistem organlar arası işlev ayrılığı esasına dayanmakta olup yönetim ve icra organı olarak kanun koyucu tarafından genel kurul değil, yönetim kurulu yetkilendirilmiştir ${ }^{10}$.

\section{YÖNETIM KURULU YETKILERININN DEVREDÍLMESİ}

Yönetim kurulu, TTK 367/1'inci madde hükmü uyarınca, konulardaki uzmanlık, deneyim vb. nedenlerle esas sözleşmenin verdiği yetkiye dayanarak görevlerinin birkaçını veya hepsini yönetim kuru lu üyelerinden birine veya birkaçına devredebilir. Bu devir bir iç yönerge metni ile gerçekleşecektir. İç yönerge yapılacak yetki devrinin esaslarını ortaya koyması bakımından önem taşımaktadır ${ }^{11}$. İlgili iç yönerge şirketin yönetimini düzenler; bunun için gerekli olan görevleri, tanımlar, yerlerini gösterir, özellikle kimin kime bağlı ve bilgi sunmakla yükümlü olduğunu belirler ${ }^{12}$.

İç yönerge ile yönetim yetkisinin devrinin muhatabı yönetim kurulu üyesi olabileceği gibi üçüncü bir kişi de olabilir. Böylelikle TTK'da ikili sisteme benzeyen esnek bir yaklaşım benimsendiği görülmektedir ${ }^{13}$. Bu sistemde yetkiyi devreden üyelere, yetki ve görevleri devralanları gözetme, bir diğer anlatımla ikili sistemde söz konusu olan gözetim kuruluna benzer şekilde çalışma görevi ve/veya imkân1 verilmiştir ${ }^{14}$. TTK 375'inci maddenin (e) bendi gereğince, yönetimle görevli kişilerin faaliyetlerini gözetim ve denetleme görevi yönetim kurulunun vazgeçilemez yetkilerinden olduğundan, üst gözetim görev ve yetkisi devrin kapsamına dâhil olamamaktadır. Nitekim Anayasa Mahkemesi tarafindan verilen bir kararda da bu hususa vurgu yapılmıştır ${ }^{15}$. Üst gözetim görevinin devre konu olamamasının, bu devrin doğrudan yetkili olmayan kurul üyelerini sorumluluktan kurtarma etkisini zayıflatabileceği belirtilmektedir. Zira, eğer kapsamı ve esasları iyi bir şekilde tayin edilmezse bir şirkette gerçekleşen bütün usulsüzlüklerden, üst gözetim görevi gerekçe gösterilerek, en geniş anlamda tüm zararlardan yönetim kurulu sorumlu tutulabilir. Ancak yetkinin devri hal inde yönetim kurulunun yal-

8 PULAŞLI, Genel Esaslar, s. 411; KIRCA / ŞEHIRALİ ÇELIK / MANAVGAT, s. 536.

9 PULAŞLI, Genel Esaslar, s. 410; KIRCA / ŞEHIRALİ ÇELIK / MANAVGAT, s. 536.

10 TEKİNALP, Ünal: Sermaye Ortaklıklarının Yeni Hukuku, 4. Baskı, Vedat Kitapçılık, İstanbul, 2015, s. 215.

11 TTK 367 MaddeGerekçesi.

12 BAHTiYAR, Mehmet: Ortaklıklar Hukuku, 15. Baskı, Beta Yayınevi, İstanbul, 2021, (Ortaklıklar Hukuku), s. 230.

13 İkili (düalist) sistemde gözetim ve yürütme kurulu olmak üzere iki ayrı organ bulunmakta ve organların görevleri konusunda kesin ve katı bir ayrıma gidilmiş bulunmaktadır. Yürütme kurulu şirket idaresinden ve şirket işlerini yürütmekten sorumlu iken gözetim kurulu ise yürütme kurulunu denetlemek gözetmek ve tavsiyede bulunmak suretiyle yürütme kuruluna yol göstermekle sorumlu tutulmuștur. Ayrıntılı bilgi için bkz. AKSOY, Mehmet Ali: "Türk Kurumsal Yönetim Düzenlemeleri Kapsamında Anonim Şirket Yönetim Kurulu", Gazi Üniversitesi Hukuk Fakültesi Dergisi, 2013 Cilt 17, Sayı 1-2, s. 54.

14 KIRCA / ŞEHIRALİ ÇELIK / MANAVGAT, s. 592. Yine bu yönde anonim şirketlerde yönetim yetkisinin devriyle birlikte şirketin uzman kişiler tarafından yönetilmesinin önünün açıldı̆̆ ifade edilmektedir. Aynı yönde bkz. CEYLAN, Nurgün: "Anonim Şirketlerde Yönetim ve Temsil Yetkisinin Devrinin Anlamı, Sonuçları ve TTK m. 371 f. 7 ile Karşılaştırılması”, Türkiye Noterler Birliği Hukuk Dergisi, 2015, Cilt 2, Say1 1, s. 6.

15 AYM, T. 30.05.2019, E. 2015/11192, K. 2019/769 (Sinerji Ị̇tihat Bankası, E.T.: 24.11.2021): “Bu bağlamda 6102 sayılı Kanun'un 375. maddesinin (1) numaral fikrasının (e) bendi uyarınca yönetim kurulunun, şirket yöneticilerinin üst gözetiminden sorumlu olduğuna dikkat çekmek gerekir. Nitekim yöneticilere gerekli talimatın verilmesi de yönetim kurulunun görevleri arasındadır. Buna göre yönetimle görevli kișilerin, özellikle kanunlara, esas sözleșmeye, iç yönergelere ve yönetim kurulunun yazll talimatlarına uygun hareket edip etmediklerinin üst gözetimi, yönetim kurulunun devredilemez görev ve yetkilerindendir. Böylece yönetim yetkisinin devredilmesi halinde yönetim kurulunun üst gözetim yetkisine sahip olduğu hükümde açıç̧ öngörülmüștür". 
nızca gözetim yetkisinin varlığına dayanılarak, yetkiyi devretmiş olmasına rağmen zararlardan sorumlu tutulmasının kanun koyucu tarafindan amaçlanmadığı TTK m. 553/3 hükmü göz önüne alındığında rahatıkla ifade edilebilirr ${ }^{16}$. Zira bahse konu hükümde açıkça bir yönetim kurulu üyesinin görevi ve yetkisi dışında kalan hususlar ile ilgili olarak sorumlu tutulamayacağı, hatta yalnızca üst gözetim ve sair görevleri olduğu için o üyeye yetkileri dışındaki konularda sorumluluk yüklenemeyeceği hüküm altına alınmıştır.

TTK'da yönetim kurulunun yetkilerini devretmesi birtakım yasal şartların yerine getirilmesine bağlı tutulmuştur. Bu bağlamda öncelikle bu konuda şirket esas sözleşmesinde buna cevaz veren bir düzenleme bulunması gerekmektedir. Bununla birlikte TTK'nın 367'nci maddesinin 1'inci fikrasında belirtilen asgari unsurları içeren bir iç yönerge metni hazırlanması ve yönetim kurulunda yetki devrine ilişkin bir karar alınması gerekmektedir ${ }^{17}$. Bununla birlikte belirtmek gerekir ki, kanun koyucu yönetim ve temsil yetkisinin devrini birbirinden ayrı olarak düzenlemiş ve 367'nci maddenin gerekçesinde açıkça bunu belirtmiştir ${ }^{18}$. Bu şekilde yönetim kurulunun yetkilerinin ayrı ayrı düzenlenmesinin anla $\mathrm{m}$, yönetim ve temsil yetkisinin ayrı ayrı ve açıçca devredilebilmesidir ${ }^{19}$. Temsil yetkisi devredilmek isteniyorsa iç yönergede bu husus ayrıca ve açıç̧a belirtilmeli ve bu halde iç yönerge tescil ve ilan edilmelidi $r^{20}$. Ayrıca belirtilmelidir ki, iç yönergede örgüt şeması verilmeli; karar ve atama yetkileri ile işletmenin teknik, ticari ve hukuki açıdan yönetimine ilişkin düzenlemeler de bulunmalıdır ${ }^{21}$. Bunun yanında yetkilerin her ne kadar ayrı ayrı devredilmesi mümkünse de bizce, yetki devredilen kişi veya kişilerin amacına uygun olarak çalışabilmesi, etkinliğin sağlanabilmesi için yönetim ve temsil yetkisinin birlikte devredilmesinde fayda bulunmaktadir.

\section{A. Yetki Devrinin Kapsamı}

Yetki devrinin kapsamının belirlenebilmesi devrin sınırının tayin edilmesiyle mümkündür. İşte bu noktada, yukarıda da değindiğimiz üzere, yetki devrinin sınırını TTK 375'inci maddede belirtilen yönetim kurulunun vazgeçilmez ve devredilemez nitelikteki yetkileri oluşturmaktadır. TTK'nın 375'inci maddesi hükmünün lafzından da açıkça anlaşıldığı üzere bu maddede sayılan yetkilerin TTK'nın 367'nci maddesi kapsamında devri mümkün değildir. TTK'nın 375'inci maddesinde sayılan yönetim kurulunun vazgeçilmez ve devredilemez nitelikteki görev ve yetkilerinin genel kurula veya başka bir üçüncü kişiye bırakılmasına kanun koyucu izin vermemiştir. Nitekim maddede sayılan görev ve yetkiler dıșında, özellikle genel kurulun bir icra organı vasfı taşımamasına bağlı olarak, genel kurula devre dilemeyecek, münhasıran yönetim kurulu tarafından yapılabilecek iş ve işlemler de bulunmaktadır ${ }^{22}$. Örneğin TTK m. 379/2 hükmü gereğince genel kurul şirketin kendi paylarının iktisabında sadece yönetimkurul unu yetkilendirebilir ${ }^{23}$.

Yetkiyi devretme iradesi taşıyanlar, TTK'nın 375'inci maddesindeki görev ve yetkiler haricinde, yönetim kurulunun uhdesine bırakılmış her çeşit iş ve işlemler hakkındaki karar alma yetkisini devrede bilirler. Burada altını çizmek istediğimiz bir başka husus ise esas sözleşmeye konulacak bir hüküm ile yetki devrine sınırlama getirilebileceğidir. Gerçekten de örneğin, esas sözleşmede yetkilerin salt yönetim kurul üyesine ya da sırf üçüncü kişiye devrinin mümkün olduğu, bir kısım yetkilerin de yönetim kurulunda kalacağı kararlaştırılabilir. Bunun dışında esas sözleşmeyle yetki devrine müdahale edilmesi

16 KIRCA / ŞEHIRALİ ÇELIK / MANAVGAT, s. 615.

17 DEMIREL, s. 221; KIRCA / ŞEHIRALİ ÇELIK / MANAVGAT, s. 599.

18 TTK 367 Madde Gerekçesi; KIRCA / ŞEHIRALİ ÇELIK / MANAVGAT, s. 593.

19 ŞENER, s. 369.

20 KIRCA / ŞEHIRALI ÇELIK / MANAVGAT, s. 600.

21 BAHTIYAR, Ortakliklar Hukuku, s. 230.

22 KIRCA / ŞEHIRALI ÇELIK / MANAVGAT, s. 533; ŞENER, s. 371. Bu hususta ömek olarak bkz. TTK m. 145, 147, 166, 169, 185, 186, 199, 353/1, 368, 376, 377, 378, 379/2, 446/1.c, 457, 461/3, 481-483, 486/2, 514, 530/1; Sermaye Piyasas1 Kanunu m. 17/3.

23 SSENER, s. 371. 
mümkün değildir ${ }^{24}$. Zira yetki devri münhasıran yönetim kurulunun gerçekleştirebileceği bir işlemdir. $\mathrm{Bu}$ şekilde kendisine yetki devredilen kişiler organ sıfatını haiz olacaklar ve bu sebeple yönetim kurulu üye

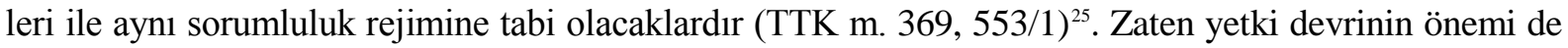
burada, yani sorumluluk bakımından doğuracağı etki yönünden önem kazanmaktadır ${ }^{26}$.

\section{B. Yetkinin Geçerli Olarak Devri}

\section{Esas Sözleşmede Yetki Devrine İzin Veren Açık Hükmün Varlığı}

TTK'nın 367 ve 370'inci maddeleri uyarınca usulüne uygun bir yetki devrinden bahsedilebilmesi için şirket esas sözleşmesinde bu konuda açık bir düzenlemenin var olması gerekmektedir ${ }^{27}$. Esas sözleşmedeki söz konusu düzenleme, şirketin kuruluş aşamasında esas sözleşme tanzim edilirken düzenlenebileceği gibi daha sonra esas sözleşmenin tadil edilmesiyle de yapılabilir ${ }^{28}$. Bu hususta yapılacak esas sözleşme değişiklikleri bakımından genel olarak halka kapalı şirketler için TTK'nın 421'inci maddesindeki nisaplar esas alınırken, halka açık şirketler için ise Sermaye Piyasası Kanunu'nun (SPKn) 29/3'üncü maddesindeki nisaplar esas alınacaktır. Dolayısıyla TTK m. 418 uyarınca halka kapalı şirketler yönünden sermayenin yarısına sahip pay sahiplerinin hazır olduğu toplantıda toplantıya katılanların çoğunluğunun olumlu oyuyla işbu karar alınabilir.

Usulüne uygun bir yetki devrinden bahsedilebilmesi için, yukarıda da değindiğimiz gibi, şirket esas sözleşmesinde bu yönde bir düzenlemenin var olması gerekir. Esas sözleşmede yer verilecek bu hükümle esasında yönetim kurulunun yetki devri yapabilmesi için gerekli şartlar sağlanmış olmaktadır. Bu konuda bir bağlantı kurmak gerekirse Türk Borçlar Kanunu'nun (TBK) 506'ncı madde hükmü, kendisine yetki verildiği hallerde vekilin işi başkasına yaptırabileceğini düzenlemiştir. Vekâlet akdine dair bu hüküm nazarında vekilin (yönetim kurulu üyesinin) işi başkasına (yetkinin devredileceği kişilere) yaptırmak için sahip olması gereken yetki, esas sözleşmedeki yetki devrine izin veren açık hükümle sağlanmaktadır29. Esas sözleşmede bu yönde hüküm bulunmaması durumunda yapılan yetki devri hukuki sonuç doğurmayacak, sorumluluk devredilmemiş olacaktır. Esas sözleşmede bu yetkinin yönetim kuruluna verilmesi uygulamada "iç yönerge çıkartılmasına izin verilmesi” olarak karşılık bulmaktadır.

\section{2. İç Yönerge Düzenlenmesi}

TTK'nın 367'nci maddesinde ifadesini bulan yönetim yetkisinin devri ancak usulüne göre yapılmış ve imza altına alınmış bir iç yönergeyle mümkün olabilecektir. Bu kapsamda usulüne uygun ola rak yapılmış bir iç yönerge esas sözleşmeden sonra yönetim ve temsil ile ilgili ikincil nitelikte bir düzenleme olarak nitelendirilebilir ${ }^{30}$. Başka bir ifadeyle esas sözleşme devre izin veren bir üst norm içermekte, iç yönerge de devrin uygulanmasına ilişkin hükümleri düzenlemektedir. Bu doğrultuda usulüne uygun bir yetki devrinin söz konusu olabilmesi için iç yönerge düzenlenmesi tek başına yeterli değildir. Şirket esas sözleşmesinde yetki devrine izin veren açık bir düzenlemenin varlığı, iç yönergenin usulüne göre toplanmış bir yönetim kurulu kararıyla kabul edilmesi ve yönetim kurulunun yetki-

24 “Örneğin ne yönetimin devredileceği kişinin esas sözleşmeyle belirlenmesi, dolayısıyla devrin bizzat esas sözleşmeyle yapılması ne yönetimin devri mecburiyeti getirilmesi, ne de esas sözleşme hükmüyle yönetimin devrinin genel kurula bırakllması mümkündür". KIRCA / ŞEHIRALİ ÇELIK / MANAVGAT, s. 601.

25 KIRCA / ŞEHIRALİ ÇELIK / MANAVGAT, s. 629; KOÇ, Himmet: Anonim Şirketlerde İç Yönerge ile Yönetim ve Temsil Yetkisinin Devri, Gazi Üniversitesi Sosyal Bilimler Enstitüsü, Ankara, 2017, s. 143.

26 GerekçeTTK m 367.

27 AYHAN / ÇAĞLAR / ÖZDAMAR, s. 317. Aksi yönde olarak bu hususta bir esas sözleşme hükmüne gerek kalmaksızın da yönetimin devrinin mümkün olduğu ileri sürülmektedir. Gerekçe olarak da böyle bir hükmün varlığının, yetkinin kullanılmasını genel kurulun uhdesine bırakabileceği ve bunun da yetkiyi devredilemez ve vazgeçilemez olmaktan çıkaracağı belirtilmektedir. Bkz. KIRCA / ŞEHIRALİ ÇELIK / MANAVGAT, s. 618.

28 KIRCA / ŞEHIRALİ ÇELIK / MANAVGAT, s. 600

29 Yukarıda ifade edilenler doğrultusunda yönetim yetkisinin devrine ilişkin esas sözleşme hükmüne örnek olarak şu gösterilebilir: “Yönetim kurulu, yönetimi, kismen veya tamamen bir veya birkaç yönetim kurulu üyesine veya üçüncü kişiye devretmeye yetkilidir".

30 PULAȘLI, Genel Esaslar, s. 39. 
sini bu iç yönergeye göre devrettiğine dair karar vermesi gerekmektedir. Son olarak devrin içeriğinin temel kanuni sınırlama niteliğindeki TTK 375'inci maddenin kapsamına girmemesi gerekir ${ }^{31}$.

Ancak burada belirtmek gerekir ki, iç yönerge yalnızca yönetim ve/veya temsil yetkisinin devri amacıyla değil, şirketin iç işleyişine dair bir düzen getirmek veya ihtiyacı karşılayabilecek gerçek bir organizasyon şeması oluşturmak amacıyla da düzenlenebilir ${ }^{32}$. Dolayısıyla iç yönerge düzenlenmesi sadece yetki devri halinde değil, yönetim kurulunun yönetim hakkını bizzat yerine getirdiği durumda da önem taşımaktadır ${ }^{33}$. Zira iç yönerge, her kademedeki yöneticinin unvanlarını, iş tanımlarını, raporlama ile bilgi akışını, yöneticiler ve yönetim yetkisini devralacak olan kişiler ile üst derece diğer şirket yöneticileri arasındaki hiyerarşiyi ${ }^{34}$, toplantılarının icrası ile kararların alınmasını ve özellikle kurumsal yönetim ilkeleri bağlamında kararların tanzimi ve icrasıyla hangi üyenin yetkili olduğunu göstermesi açısından belirleyici olmaktadır. Bu bağlamda yetki devri söz konusu olmasa dahi iç yönerge düzenlenmesi şirket işleyişi bakımından faydalı olabilmektedir. Zira iç yönerge şirketin işletme konusunu gerçekleştirmeye yönelik iş ve işlemlerde genel ve temel nitelikte bir düzen temin etmektedir. İç yönerge ile yetki devri yapılması durumunda ise söz konusu yetkiler konunun uzmanları tarafindan kullanıldığından yönetim profesyonel bir nitelik kazanmakta, böylece daha hızlı ve etkili kararlar alınabilmesi mümkün olmaktadır. Öyle ki iç yönerge, özellikle yönetici sayısı fazla olan büyük şirketlerde, karar alınmasını kolaylaştırmaya; bunun yanında şirketin profesyonellerce yönetilmesine ve işlerin daha kurumsal bir yapı içerisinde yürütülmesine hizmet etmektedir ${ }^{35}$.

\section{3. İç Yönergenin Kabulüne Dair Yönetim Kurulu Kararı Alınması}

Usulüne uygun bir devir için iç yönergenin kabulüne yönelik TTK'nın 390'ıncı maddesindeki nisaplara uyularak yönetim kurulu kararı alınması gerekmektedir ${ }^{36}$. Bu yönde bir yönetim kurulu kararının alınması hususunda belirli pay gruplarına imtiyaz tanınabileceği ve iç yönergeye dair alınacak yönetim kurulu kararlarının bu imtiyazlı paylara sahip üye(ler)in olumlu oyu ile alınmasının zorunlu kılınabileceği kanaatindeyiz. Buna ek olarak esas sözleşmede iç yönergeyle ilgili kararların daha yüksek bir karar nisabına bağlanması da mümkündür.

Belli şartlarda yönetim kurulu kararlarının iptale konu olabileceğine doktrinde ve yargı kararla rında ${ }^{37}$ işaret edilmektedir. Bu kapsamda iç yönergeyle ilgili yönetim kurulu kararının batıl olduğunun tespitinin de mahkemeden istenebilmesi TTK'nın 391'inci maddesi uyarınca mümkün olabilmektedir. Konumuzla sınırlı olarak kısaca şunu ifade etmek isteriz ki, yetki devrinin ve buna ilişkin kararların batıl olduğu elbette ilgili hüküm kapsamında ileri sürülebilmelidir. Böylelikle iç yönergenin amacı dışında kullanılmasının önüne geçilebilir. Örneğin olası bir ihtilafta TTK'nın 391'inci maddesinin (b) veya (d) bentleri uyarınca yönetim kurulunun üst gözetim görevini de iç yönergeyle devrettiğine dair bir kararın batıl olduğu ileri sürülebilecektir ${ }^{38}$.

\section{Yetki Devrinin Mümkün Olması}

Yukarıda da değindiğimiz üzere, yönetim kurulu tarafından devre konu edilen yetkiler TTK'nın 375'inci maddesinde sayılan vazgeçilemez ve devredilemez nitelikteki yetkilerden olmamalıdır. An-

\footnotetext{
31 KIRCA / ŞEHİRALİ ÇELİK / MANAVGAT, s. 599.

32 PULAŞLI, Genel Esaslar, s. 412; KIRCA / ŞEHİRALİ ÇELİK / MANAVGAT, s. 604.

33 PULAŞLI, Genel Esaslar, s. 412.

34 AYHAN / ÇAĞLAR / ÖZDAMAR, s. 317.

35 DEMIREL, S. 244.

36 TTK 390/1 hükmü uyarınca esas sözleşmede iç yönergenin kabulü için ağırlaştırıcı bir hüküm olmadığı müddetçe, yönetim kurulu üye tam sayısının çoğunluğu ile toplanacak ve kararını toplantıda hazır bulunan üyelerin çoğunluğu ile alacaktır. Bkz. KIRCA / ŞEHİRALİ ÇELIK / MANAVGAT, s. 604.

37 ERİŞ, Gönen: Anonim Şirketler Hukuku, 1. Baskı, Seçkin Yayıncılık, Ankara, 1995, s. 268; ÖZKORKUT, Korkut: Anonim Ortaklıklarda Yönetim Kurulu Kararlarının Íptali, Sermaye Piyasası Kurulu Yayınları, Ankara, 1996, s. 93 vd.

38 KIRCA / ŞEHİRALİ ÇELIK / MANAVGAT, s. 520.
} 
cak vazgeçilmez ve devredilemez nitelikteki görev ve yetkiler dışında kalan yetkilerin devri mümkün kılınmıştır. Bu noktada şu soru karşımıza çıkmaktadır; temsil yetkisinin tamamının kurul üyesi olmayan üçüncü kişilere devri mümkün müdür? Bu hususta TTK'nın 370/2'deki hükmü temsil yetkisinin tamamının üçüncü kişilere devrine engel olmaktadır ${ }^{39}$. Düzenlemedeki en az bir kurul üyesinin temsil yetkisine sahip olması gerektiği kuralı gereğince yönetim kurulunun yukarıda bahsettiğimiz gibi ta mamen gözetim kurulu gibi çalışmasına olanak tanınmamıştır ${ }^{40}$.

$\mathrm{Bu}$ durumda şirketin temsili görevinin tamamen üçüncü kişilere devrinin mümkün olmadığ ifade edilebilir. Mülga 6762 sayılı TTK'da da aynı hüküm mevcut olup bu durumun benimsenen tekli sistemin bir sonucu olduğu görülmektedir. Neticede Türk hukuku bakımından gözetim ve icra organı olmak üzere iki ayrı yapılanmaya gidilmesine izin verilmemiştir. En az bir yönetim kurulu üyesinin temsil yetkisine sahip olması şartıyla yetki devri gerçekleştirilebilir.

\section{III. İÇ YÖNERGE}

Yönetim kurulunun temsil yetkisinin devredildiği kişiye "murahhas üye (delegierte)" adı verilmektedir $r^{41}$. Benzer şekilde, yönetim kurulu üyesi olmayan kişiye yapılan devirde bu kişi de "murahhas müdür (direktoren)" olarak anılmaktadır ${ }^{42}$. Bu kapsamda murahhaslara yetki devri, yukarıda da değindiğimiz üzere, yönetim kurulunca yazılı şekle tabi bir iç yönerge düzenlenmesiyle mümkün olmakta dır. Doktrinde iç yönergelerin anonim şirketler hukuku bakımından oldukça önemli bir mekanizma olduğu isabetli bir şekilde ifade edilmektedir ${ }^{43}$. Bu açıdan açıkça Kanun'da bir zorunluluk olmasa da kurumsal yönetim ve verimliliğin artırılması vb. nedenlerle şirketlerin iç yönerge çıkarması oldukça yerinde bir durum olacaktır. Başka bir ifadeyle gerek düzenlemenin lafzından gerekse Kanun'un gerekçesinden anlaşıldığ üzere, yönetim veya temsil yetkisi devredileceği zaman bir iç yönerge hazırlanması gerekmektedir. Ancak burada belirtmek istediğimiz husus şirketlerin iç yönerge düzenlemesinin bir zorunluluk olmadığıdır. Zira böyle bir önerme de yerinde olmayacaktır. Çünkü yönetimin devriyle amaçlanan sorumluluğun sınırlandırılması ve iç yönergenin şirkete getireceği düzen veya iş bölümü uygulamasıdır. Bu uygulamalar da şirketin işletme hedeflerine ulaşması için bir araç olarak kendini gösterecektir. Bu araç ise beraberinde aynı yönde bir iradenin varlığını gerektirmektedir. Bu kapsamda iç yönergenin anonim şirket için bir zorunluluk olmadığı ifade edilebilir. Dolayısıyla iç yönergenin şirket içi düzeni temin etmesi, bilgi akışı sağlaması ve kurumsallaşmaya hizmet etmesi gibi faydalar sağlaması nedeniyle önemli bir araç olarak değerlendirilebileceği kanaatindeyiz.

İç yönergenin şirketlerde yetki devrinin usulüne uygun olarak yapılıp yapılmasının doğuracağ1 hukuki sonuçlar bakımından önemi bulunmaktadır. Zira iç yönergeye dayanmaksızın, yahut iç yönerge hükmüne aykırı olarak gerçekleştirilen yetki devri TTK m. 367/1 hükmü uyarınca öngörülen hukuki sonuçları doğurmayacak, kendisine yetki devredilen kimsenin yaptığ işlemler geçersiz olacak, şirket bu işlemlerle bağlı olmayacaktır ${ }^{44}$. Bu anlamda usulüne aykırı bir yetki devri durumunda iç yönergeyle temin edilmeye çalışılan sorumluluğun sınırlandırılması da mümkün olmayacaktır. Fiilen gerçekleştirilen yetki devri TTK m 553/2 uyarınca yönetim kurulunun sorumluluğunu etkilemeyecek, kurulun

39 Maddeye göre “... En az bir yönetim kurulu üyesinin temsil yetkisini haiz olması şarttır”. Bu nedenle yönetim kurulu temsil yetkisini tamamen kurul dışındaki kişilere devrederek kendini tam sorumsuz konuma sokamaz (TTK m. 370/2).

40 KUTGİ TAŞAN, Ayşe Selcen: Anonim Şirketlerde Temsil Yetkisinin Yönetim Kurulu Tarafindan Kullanılması, İstanbul Ticaret Üniversitesi Sosyal Bilimler Enstitüsü, İstanbul, 2019, s. 69.

41 Ancak önemle belirtmek isteriz ki, İsviçre hukukunda murahhas anlamına gelen “delegierte” kavramı, İsviçre Borçlar Kanunu m. 718/2 uyarınca sadece temsil yetkisinin devredilmesinde kullanılmakta buna karşın yönetimin devrinde ise söz edilmemektedir. Ayrıntılı bilgi için bkz. PULAŞLI, Şerh, s. 1355.

42 PULAȘLI, Serh, s. 1354; ȘENER, s. 369.

43 Özellikle işçilerin tabi olacakları kuralları içeren metinler olmaları ve şirket içi düzeni sağlaması bakımından iç yönergelerin büyük önem taşıı̆ı̆ı ifade edilmektedir. Bkz. KOÇ, Himmet: "Anonim Şirketlerde İç Yönerge ve İç Yönergenin Benzer Hukuki Kurumlarla Olan İlişkisi”, Medeniyet ve Toplum Dergisi, 2017, Cilt 1, Sayı 2, (İ̧̧ Yönerge), s. 3.

44 DEMIREL, s. 227; ORAN, Ozan: Anonim Şirketlerde Yönetim Kurulu İç Yönergesi, İstanbul Üniversitesi Sosyal Bilimler Enstitüsü, İstanbul, 2019, s. 34; KOÇ, s. 29. 
sorumluluğu aynen devam edecektir. Oysaki iç yönerge düzenlenmesindeki temel gaye yönetim kurulunun sorumluluğunun sınırlandırılmasıdı ${ }^{45}$. Dolayısıyla yetki devrinin amaca hizmet edebilmesi devrin iç yönergede belirlenen hususlara uygun olarak yapılmış olmasına bağlıdır.

$\mathrm{Bu}$ aşamada konumuzla dolaylı olarak ilintili olduğu için yetkisiz temsil hususuna değinmekte fayda görmekteyiz. TBK hükümleri dairesinde temsil yetkisinin bulunmadığı ya da mevcut yetkinin sınırlarının aşıldığı durumlarda yetkisiz temsilden bahsedilebilir ${ }^{46}$. Yetkisiz temsilcinin yaptığı hukuki işlem ancak temsil olunan tarafindan onandığı takdirde bağlayıcı hale gelmektedir ${ }^{47}$. TBK $m$ 46/2 hükmünden çıkardığımız sonuca göre bu onamın verilmediği durumlarda ise üçüncü kişilerin uğradıkları zararlardan yetkisiz temsilci sorumlu olabilecektir. Durum bu olmakla birlikte TBK üçüncü kişilerin zararların gide rilmesi taleplerinin kabulünü iyiniyetli olmaları şartına bağlamıştır (TBK m. 47/1). Bu açıdan bakıldığında TTK m. 371/7 hükmü uyarınca yapılacak yetki devri için hazırlanan iç yönergenin tescil veilana tabi olduğu kuralının göz önünde bulundurulması gerekir. Buradaki tescilin açıklayıcı nitelikte olduğu ifade edilmektedir ${ }^{48}$. TTK m 36 uyarınca tescil ve ilanın en temel hukuki sonucu ise üçüncü kişilerin iyiniyetini ortadan kaldırmasıdır. Öyle ki iç yönerge ile kendisine yetki devredilen kişilere ilişkin muhtemel bir yetkisiz temsil tartışmasında, iç yönergenin tescil ve ilanı zorunlu olduğundan yetkisiz temsille ilgili tartışmaların en baştan önüne geçilmiş olmaktadır ${ }^{49}$. Zira tescil, muhtemel iyiniyet iddiasını ortadan kaldırmakta; iç yönergeye göre atanmış ve bu atama kararı tescil edilmiş bir temsilcinin yaptığı işlemlerden doğan hak ve borçlar temsil edilene, yani şirket tüzel kişiliğine ait olmaktadır.

\section{IV. ŞİRKET VE YÖNETIM KURULU ÜYELERİ ARASINDAKİ HUKUKİ İLIŞKI}

Yönetim kurulu üyelerinin sorumluluğu konusunda öncelikle şirket ile kurul üyeleri arasındaki ilişkinin niteliğini tespit etmekte fayda vardır. Zira bu durumun açıklığa kavuşturulması, tarafların hukuki sorumluluğunun ve haklarının belirlenmesi, sorumluluk şartlarının incelenmesi, görevli mahkemenin tespiti ve sorumluluktan kurtulma şartları ile zamanaşımı konularının incelenmesi hususunda temel teşkil edecektir ${ }^{50}$. TTK'nın 126'ncı maddesinin atfı ile TBK m. 630 hükmü ${ }^{51}$ birlikte ele alındığında şirket ile yönetim kurulu üyeleri arasındaki ilişsinin, yukarıda da işaret ettiğimiz gibi, "vekâlet" niteliğinde olduğu isabetli olarak savunulmaktadır ${ }^{52}$. Bunun yanında bu ilişkinin hizmet sözleşmesi niteliğinde olduğunu savunan yazarlar da bulunmaktadır ${ }^{53}$.

45 AYHAN / ÇAĞLAR / ÖZDAMAR, s. 317.

46 KILIÇOĞLU, Ahmet: Borçlar Hukuku Genel Hükümler, 25. Basım, Turhan Kitabevi, Ankara, 2021, s. 336.

47 İcazet verilmediği halde susmanın onam anlamına geldiği yönünde bkz. Yargıtay, 11. HD., T. 30.11.1993, E. 1992/9367, K. 1993/8158: “... Yetkisiz temsilde temsil edilenin, yetkisiz temsilcinin kendi adına imza atmasına ses çıkarmayarak, yetkisiz temsil imzasının sonuçlarını yüklendiği durumlarda sorumluluğu vardır".

48 KOÇ, s. 12.

49 Doktrinde anonim ve limited şirketler dışında kalan gerçek kişi tacirler ile kollektif, komandit ve paylı komandit şirketler açısından aynı düzenleme getirilmemesi eleștirilmektedir. Bu bağlamda örneğin bir komandit șirkete atanan, sinırlı yetkiyi haiz ticari vekil ile diğer ta cir yardımcılarının yetkileri sınırlandırılsa bile tescil ve ilan edilemeyeceğinden üçüncü kişileri bağlamayacaktır. Somutlaştırmak gere kirse A Bankası "Bu ticari vekil temsil yetkisini assmıștır, bu ișlemle bağlı değilim.” diyebilirken B Kollektif Sirketi, aynı gerekçeyi ileri süremeyecektir. Dolayısıyla Anayasa'nın eşitlik ilkesine aykırı olarak düzenleme yapıldığı ifade edilmektedir. Yine bu düzenlemenin hiç kimsenin ticaret siciline bakmadan işlem yapamaması gibi bir sonuç doğuracağı ve yapılan her işlem dolayısıyla şirketin sorumsuzluk iddiaları ile karșı karșıya kalınacağı serdedilmektedir. Bkz. AKDAĞ GÜNEY, Necla: "6552 Sayılı Torba Kanun ile TTK md. 371'eEklenen 7'nci Fikraya İlişkin Değerlendirmeler", (6552 Sayılı Torba Kanun),

(http://www.arslanlibilimarsivi.com/node/25, E.T.: 14.03.2021), s. 4, 21.

50 KIRCA / ŞEHIRALİ ÇELIK / MANAVGAT, s. 453; AYHAN / ÇAĞLAR / ÖZDAMAR, s. 306; BALABAN, MahmutFurkan: Anonim Şirket Yönetim Kurulu Üyelerinin Hukuki Sorumluluğu ve Sorumluluk Davası, Ufuk Üniversitesi Sosyal Bilimler Enstitüsü, Ankara, 2019, s. 58; KAPLAN, İbrahim: "6102 sayılı YTTK Hükümlerine Göre Şirket Yönetim Kurulu Üyeleri ve Diğer Üst Yöneticilerin, Sirkete, Ortaklara ve Şirket Alacaklılarına Karşı Hukuki Sorumluluğu”, Ankara Üniversitesi Hukuk Fakültesi Dergisi, 2016, Cilt 65, Sayı 4, s. 3501.

51 TBK'nın 630'uncu maddesinde yer alan “Kanunun bu bölümünde veya ortakllk sözleşmesinde aksine hüküm bulunmadlkça, yönetici ortaklar ile diğer ortaklar arasındaki ilișkiler, vekâlet sözleșmesine ilişsin hükümlere tabidir." hükmü amirdir.

52 KIRCA / ŞEHIRALİ ÇELIK / MANAVGAT, s. 456-458. Şirket ile kurul üyesi arasında vekâlet ilişsisi olduğu yönünde bkz. AYHAN / CAĞLAR / ÖZDAMAR, s. 305; Yargitay da verdiği bir kararda "Sirket yönetim kurulu üyeleri ile sirket arasinda bir vekâlet akdi iliskisi bulunduğundan, üyelerin şirkete karşı vekil gibi sorumlu olmaları doğaldır." şeklinde tespitlerde bulunmuştur. Bkz. Yargitay, HGK, T. 07.07.2010, E. 2010/9-328, K. 2010/370 (Sinerji İçtihat Bankas1, E.T.: 28.11.2021).

53 AKDAĞ GÜNEY, Necla: Anonim Şirket Yönetim Kurulu, 2. Baskı, Vedat Kitapçılık, İstanbul, 2016, s. 176. 
Ücret ve uzun süre bir iş sahibine bağımlılık içerisinde hizmet etmek hizmet sözleşmesinin objektif esaslı noktalarındandır (TBK m. 393 vd.). Nitekim Yargıtay da hizmet sözleşmesinin objektif esaslı noktaları hususunda ücret, iş görme ve bağımlılık unsurlarına işaret etmiştir ${ }^{54}$. Buna karş1lık, bizim de katıldığımız yaklaşıma göre yönetim kurulu üyesi/üyelerinin şirketten ücret alıyor olması, şirket ile kurul üyesi arasındaki ilişkinin "temel unsuru” olmadığından sözleşmenin hizmet akdi olarak değerlendirilmesi isabetli değildirr ${ }^{55}$. Bu konuda ücret, aradaki ilişki bakımından objektif esaslı nokta değildir. Hukuki kavramın tanımında var olan ve bu kavramın esaslı bir parçasını oluşturan hususlar genel olarak objektif esaslı konular olarak tanımlanmaktadır ${ }^{56}$. Bu bağlamda şirket ile yönetim kurulu ara sındaki ilişkiye nitelik kazandıran temel hususun ücret olmadığı görüşüne katılmaktayız. Çünkü bir organ olarak görev ifa eden yönetim kurulunun "ana işlevi” şirketin yönetimi ve temsilidir. Kaldı ki yönetim kurulu üyeliği görevini ifa karşılığında ödenen para ücret değil huzur hakkı olarak karşımıza çıkmakta olup ücret ve huzur hakkı birbirlerinden tamamen farklı kavramlardır. Bu konuda ücretin bir şirketler hukuku kavramı olmadığı ifade edilebilmekle birlikte, Yargıtay kararlarında da huzur hakk1nın İş Kanunu kapsamında bir hak olmadığına açıkça işaret edilmektedir ${ }^{57}$. Bu kapsamda huzur hakkı, yönetim kurulu üyelerinin yönetim/temsil görevi için harcadıkları emeğin veya zamanın bir karşıllğı olarak ödenen meblağ olarak tanımlanmakta ve ücret kavramından tamamen ayrışmaktadır ${ }^{58}$. Bu açıdan yönetim kurulu üyeleri ile şirket arasındaki ilişkinin hizmet sözleşmesine dayandığ fikrine bizler de katılmıyoruz. Yönetim kurulu üyesi/üyeleri ile şirket arasındaki ilişkinin vekâlet akdi ilişkisi oldur ğu görüşünde üyelerin şirkete karşı vekil gibi sorumlu olduğu ileri sürülmektedir ${ }^{59}$. Mevcut ilişkinin hukuki niteliğinin vekâlet sözleşmesi olduğu görüşünün bir diğer ve belki de en önemli dayanağı ba ğımlılık unsurudur. Gerçekten de iş sözleşmesinin karakteristik unsuru olan bağımlılık, şirket ile yönetim kurulu üyesi arasındaki ilişkide temel unsur değildir ${ }^{60}$. Bu nedenlerle öncelikle şirket ile kurul üyeleri arasında sözleşmesel bir ilişki bulunduğu kabul görmekte, sonrasında ise bu ilişkinin niteliğinin vekâlet sözleşmesi olduğu ileri sürülmektedir ${ }^{61}$. Kanaatimizce de niteliği bakımından şirketyönetim kurulu ilişkisi vekâlet sözleşmesinin unsurlarını taşımaktadır.

\section{YÖNETIMM KURULU ÜYELERİ VE YÖNETICILERİN SORUMLULUĞU}

\section{A. Genel Olarak Yönetim Kurulunun Hukuki Sorumluluğu}

Anonim şirket yönetim kurulu üyelerinin sorumluluğu ile kastedilen, kendilerine esas sözleşme ve/veya kanun tarafindan yüklenen yükümlülükleri kusurları ile yerine getirmemelerinden sınırsız ve şahsi olarak sorumlu tutulmalarıdır ${ }^{62}$.

Yönetim ve temsil yetkilerini haiz yönetim kurulunun şirket ad ve hesabına yaptığı iş ve işlemlerden dolayı şirket hak elde etmekte ve borç altına girmektedir. Yönetim kurulu veya yöneticiler şirketi bu şekilde haklara ehil ve borçlardan sorumlu hale getirirken, kendilerine yüklenen görev ve yükümülükleri yerine getirmediklerinde şirkete karşı sorumlu olacaklardır. Ticaret Kanunu'nun yöneticilere karşı sorumluluk davası açma olanı tanıdığı pay sahipleri ve alacaklılar açacakları davalarda sözleşmeye aykırılık sebebine

54 Yargitay, 9. HD., T. 30.01.2013, E. 2010/241994, K. 2013/3671 (Sinerji İçtihat Bankası, E.T.: 28.11.2021).

55 Yargıtay, HGK, T. 05.02.2003, E. 2003/982, K. 2003/65 (Sinerji İçtihat Bankası, E.T.: 28.11.2021).

56 KILIÇOĞLU, s. 86.

57 Yargitay, 2. HD., T. 27.10.2015, E. 2014/15625 K. 2015/30078 (Sinerji İçtihat Bankas1, E.T.: 24.11.2021).

58 Yargitay, 11. HD., T. 10.05.2010, E. 2010/5400, K. 2010/5060 (Sinerji İçtihat Bankası, E.T.: 26.11.2021).

59 Yargitay, HGK, T. 07.07.2010, E. 2010/9-328, K. 2010/370 (Sinerji İçtihat Bankası, E.T.: 23.11.2021).

60 Durum bu olmakla birlikte her somut duruma göre yönetim kurulu üyesinin çalışma koşulları, bu anlamda emir ve talimat alıp almadığı, sigorta primlerinin hangi esaslara göre yatırıldığı gibi noktalara bakılmalıdır. Ayrıntılı bilgi için bkz. AYHAN / ÇAĞLAR / ÖZDAMAR, S. 306.

61 KIRCA / ŞEHIRALİ ÇELIK / MANAVGAT, s. 456-458. Şirket tüzel kişiliği ile kurul üyesi arasındaki ilişkinin vekâlet ilişkisine yakın olduğu yönünde bkz. AYHAN / ÇAĞLAR / ÖZDAMAR, s. 305; Yargitay, 9. HD., T. 07.07.2011, E. 2011/2810, K. 2011/23208 (Sinerji İçtihat Bankası, E.T.: 26.11.2021).

62 AKDAĞ GÜNEY, Yönetim Kurulu, s. 165-167; AYHAN / ÇAĞLAR / ÖZDAMAR, s. 470; PULAȘLI, Genel Esaslar, s. 629-633. 
dayanabilirler ${ }^{63}$. Mülga kanunun aksine 6102 sayll TTK sistematiğinde 549 ilâ 561'inci maddeleri ile yönetim kurulu üyelerinin ve yöneticilerin sorumluluğuna ilişkin tüm düzenlemelerin isabetli bir şekilde bir araya toplandığı ve bu şekilde düzenlemelerin birlik arz edecek hale getirildiği görülmektedir ${ }^{64}$.

Yönetim kurulu üyeleri ile şirket arasındaki ilişkinin vekâlet ilişkisi olduğuna ve dolayısıyla sözleşmesel bir ilişkinin mevcut olduğuna yukarıda değinmiştik. Ancak sorumluluğun belirlenmesinde, tek başına sözleşme ilişkisi görüşü yeterli olmamaktadır. Yönetim kurulu üyelerinin hukuki sorumluluklarının tayininde, hem sözleşmesel ilişki hem de haksız fiil sorumluluğunun dikkate alınması gerektiği görüşüne katılmaktayız ${ }^{65}$. Zira TTK m 553 hükmüne bakıldığında sorumluluğun kaynağı olarak bunlardan herhangi birinin dışlanmadığı görülmektedir. Hükmün gerekçesine bakıldığında bizim inceleme konumuz ile doğrudan ilgili olan yönetim kusurunun açık bir sorumluluk hali olarak düzenlendiği görülmektedir. Burada önemle belirtmek gerekir ki, yargı mercileri yönetim kurulu üyelerinin sorumluluğunu yerindelik incelemesi yapmak suretiyle değil, kanun ve esas sözleşmeden doğan yükümlere aykırılık olup olmadığını dikkate alarak tespit etmektedir. Nitekim Yargıtay vermiş olduğu bir kara rında “... bu itibarla, davalı yönetim kurulu üyelerinin durumları anılan yasa maddeleri uyarınca değerlendirilerek oluşan davacı zararlarından dolayı sorumluluklarının bulup bulunmadığının somut olayın özelliklerine göre tartışılarak sonucu kararlaş̧tırması ${ }^{660}$, şeklinde bu hususa vurgu yapmıştır.

6762 sayılı mülga TTK'da kabul edilmiş olan müteselsil sorumluluk ilkesinden farklı olarak 6102 sayılı TTK'nın kabul ettiği farklılaştırılmış teselsül ilkesine göre bir zararın varlığından söz edilebilmesi için bunun ispatlanması ve miktarının hesaplanabilmesi gerekmektedir ${ }^{67}$. Anonim şirketler hukukunda sorumluluğun temeli kusura dayanmaktadır ${ }^{68}$. Zira TTK sistematiği kusursuz sorumluluk ilkesini benimsememiş, bu türden sorumluluk için açıkça kusurlu davranışı bir unsur olarak kabul etmiştir. Kasıt yahut ihmal şeklinde gerçekleşen kusur, hukuk düzeni tarafindan istenmeyen bir davranışın yapıılması şeklinde tanımlanabilmektedir ${ }^{69}$. Böylelikle TTK'nın 553'üncü maddesinde açıç̧a vurgulandığı üzere kanundan veya esas sözleşmeden kaynaklanan yükümlülüklerin ancak kusurla ihlal edilmesi halinde sorumluluğun söz konusu olabileceği anlaşılmaktadır. Burada hemen belirtmek gerekir ki, çalışmamızın odak noktasını oluşturan TTK m. 371/7 hükmünün son cümlesi kusura dayanan sorumluluk-kusurstz sorumluluk ayr1$\mathrm{m} ı$ da yapmamış olup maddede belirtilen kişilerin verecekleri her türlü zarardan yetkiyi devreden üyelerin müteselsil olarak sorumlu olacağını düzenlemiştir. Dolayısıyla 6552 sayılı Kanun'la getirilen düzenleme, kusura dayanan sorumluluğa ilişkin temel ilkelere de aykırılık taşımaktadır.

\section{YETKİ DEVRINIIN SORUMLULUĞA ETKİSI}

Anonim şirketlerde yöneticilerin, yönetim kurulunun ve üyelerinin sorumluluğu konusu esasında TTK m 553/2 ile hüküm altına alınmış ve bu maddede sorumluluğun temel ilkeleri düzenlenmiştir. $\mathrm{Bu}$ ilkelere göre eğer yönetim kurulu üyeleri usulüne uygun şekilde bir yetki devri yapmışlarsa ve bu yetki devrini yaparken yetkiyi devralacak kişilerin seçiminde makul derecede özen göstermişlerse artık yetkiyi devralan kişilerin kusurlarıyla meydana gelen zararlardan sorumlu tutulmayacaklardır.

TTK'nın 367, 370 ve 371/7 hükümleri uyarınca yapılan yetki devri, kanuna dayanan ve kanuna uygun olan devir olarak karşımıza çıkar ${ }^{70}$. Yukarıda ayrıntılı olarak ifade ettiğimiz üzere usulüne uy-

63 POROY, Reha / TEKİNALP, Ünal / ÇAMOĞLU, Ersin: Ortaklıklar Hukuku I, 14. Bask1, Vedat Kitapç1lık, İstanbul, 2019, s. 390.

65 BAHTIYAR, Ortaklıklar Hukuku, s. 396.

66 Yargitay, 23. HD., T. 23.09.2019, E. 2016/4567, K. 2019/4567 (Sinerji İçtihat Bankası, E.T.: 26.11.2021).

67 OKTAY KILIÇ, Duygu: Anonim Şirketlerde Yönetim Kurulu Üyelerinin Hukuki Sorumluluğu, Dicle Üniversitesi Sosyal Bilimler Enstitüsü, Diyarbakır, 2016, s. 46.

68 AYHAN / ÇAĞLAR / ÖZDAMAR, s. 476.

69 KILIÇOĞLU, s. 319; OĞUZ, Habip: “Sorumluluk Hukukunda Kusur”, Türkiye Adalet Akademisi Dergisi, 2016, Cilt 1, Sayı 28, s. 273.

70

TTK m 553 hükmünün gerekçesinde de belirtildiği üzere, 553/2 organsal işlev olarak devir halinde söz konusu olmaktadır. Maddede yer alan "kanundan veya esas sözleşmeden doğan bir görevi veya yetkiyi, kanuna dayanarak, başkasına devreden organlar veya kişiler, bu görev ve yetkileri devralan kişilerin seçiminde makul derecede özen göstermediklerinin ispat edilmesi hali hariç, bu kişilerin fiil ve kararlarından sorumlu olmazlar" hükmü amirdir. 
gun bir yetki devri için bir iç yönerge hazırlanmalı, bu iç yönergede devrin çerçevesi çizilmeli ve en nihayetinde bir yönetim kurulu kararıyla iç yönergeye uygun olarak yetki devri gerçekleştirilmelidir. TTK'nın 367, 370 ve 371/7'nci hükümlerine göre Kanun' daki usule ve esasa uygun olarak yetki devredildiği takdirde iç yönergeye göre yetkili/görevli olmayan üyelerin veya zarara sebebiyet verdiği iddia edilen eylem ile ilgili görevli olmayan yöneticilerin/üyelerin sorumluluktan kurtulması söz konusu olmalıdır. Zira hüküm uyarınca yetkinin devredildiği kişilerin seçiminde gerekli özenin gösterilme si şartıyla bu kişilerin eylemlerinden yönetim kurulu sorumlu olmayacaktır ${ }^{71}$.

Söz konusu özen yükümlülüğ̈̆² yalnızca yetkinin devredildiği kişilerin seçimi sırasında değil, bu kişilere şirketin işletme konusunu gerçekleştirmeye yönelik iş ve işlemlerle ilgili talimat verilmesi sırasında da devam etmektedir. Yukarıda da ifade ettiğimiz gibi, anonim şirket ile kurul üyeleri arasında vekâlet ilişkisi olduğundan vekalete ilişkin TBK'nın 507/2 hükmü uygulama alanı bulmalıdır. TBK'nın 507/2 hükmünde"Vekil başkasına vekâlet vermeye yetkili ise, talimat vermede gerekli özeni göstermekle yükümlüdür" hükmü amirdir. Dolayısıyla bu düzenleme gereğince yetkiyi devreden kişilerin özen yükümlülüğü sadece yetkinin devredildiği kişilerin seçiminde değil, bu kişilere talimat verilmesi sırasında da devam edecektir.

Kanun koyucu her ne kadar sorumsuzluğun temini için yönetim kuruluna gözetim açısından özen şartı getirse de bu durumun bir sakıncası bulunmaktadır. Yönetim kurulunun uhdesinde kalan, devredilemez ve vazgeçilemez nitelikteki üst gözetim yükümlülüğünün ${ }^{73}$, üyeleri sorumluluktan kurtarma etkisini zayıflattığı ileri sürülmektedir ${ }^{74}$. Zira özellikle ticari hayatta yönetim kurulu üyelerinin hayatın normal akışına aykırı şekilde, bir insanın yapabileceğinin çok üstünde, oldukça kapsamlı bir gözetim yükümlülüğü ile her türlü zarardan doğrudan sorumlu olmalarına neden olacak bir yaklaşımın benimsendiği gözlemlenmiştir ${ }^{75}$. Dola yısıyla Türk hukukunda benimsenen sistemde gözetim yükümlülüğünün sınırlarının belirsiz olması, yetki devriyle temin edilmek istenen yönetim kurulunun sorumluluğunun sınırlandırılması etkisini zayıflatmak$\operatorname{tadır}^{76}$. Ancak konumuzla sınırlı olarak şunu ifade etmeliyiz ki, kanaatimizce yönetim kurulu esas sözleşmedeki açık bir hükme dayanarak yukarıda ifade ettiğimiz usule uygun bir iç yönerge hazırlar ve bunu da tescil/ilan ettirirse sorumluluk buna göre belirlenmelidir. Yani söz konusu iç yönerge metni nde yetki dere celerine göre ayrı ayrı nelerin yetki devri kapsamına girdiği belirtilir ve bu metin ticaret siciline tescil/ilan ettirilirse sorumluluğun tayini artık yapılan yetki devrine göre gerçekleşmelidir. Bu kapsamda iç yönergede yönetim kurulunun kendi arasında veya diğer yöneticilere yetki devri yapılması esnasında kurulun açıça özensiz ve dikkatsiz davrandığı ispat edilemediği sürece yetkiyi devralan kişilerin eylemleri ile oluşan şirket zararlarından, bu konuda kendilerine doğrudan bir kusur atfedilememesi şartı ile, diğer yetkisiz üyele rin/kurulun sorumlu olmaması gerekmektedir. Bizce TTK 367, 370, 371 ve 553' üncü maddeleri beraber değerlendirildiğinde amaçsal yorum ile bu sonuca ulaşılabilmelidir. Aksi yaklaşımın TTK'nın sorumluluk ve iç yönerge ile ilgili temel anlayışına ters düştüğü kanaatindeyiz.

Burada yine belirtmek gerekir ki, yönetim kurul unun devredilemez ve vazgeçilemez nitelikteki üst gözetim görevini etkin bir şekilde yerine getirebilmesi aslında yetkinin devredildiği kişilerin sağladığı bilgi akışına bağlı olmaktadır ${ }^{77}$. Kapsamlı bir gözetim ancak ve ancak yetki devrinden sonra sağlanacak

71 “Bu kapsamda, örneğin, daha önce uzun süreler SGK müfettişi olarak görev yapmış ve bu deneyimine güvenilerek șirkete insan kaynaklarından sorumlu murahhas müdür olarak atanmış bir kişinin yaptığ yolsuzluk sebebiyle ortaya çıkan zarardan kişinin atanmasında gerekli özeni göstermiş yönetim kurulu üyelerinin şahsen sorumlu olması hukuken mümkün değildir".

(http://inanaras.com/files/Anonim\%20Sirketlerde\%20Y etki\%20Devi\%20ve\%20Devrin\%20Sorumluluga\%20Etkisi.pdf, E.T.: 27.12.2020).

Olası bir sorumluluk davası durumunda; gereken özenin gösterilip gösterilmediğinin ispat yükü, mehaz İsviçre Borçlar Kanunu'na göre yetkiyi devredendedir. Zira yetkiyi devreden, şirketin iç organizasyonu hususunda bilgi sahibi durumunda olup ispat yükü onun üzerinde olmalıdır. Bu hususta bkz. KIRCA / ŞEHIRALİ ÇELIK / MANAVGAT, s. 616.

73 Doktrinde gözetim yükümlülüğü iki ucu keskin bir kılıca benzetilmektedir. Öyle ya da böyle işlevsiz hale getirilirse yönetim kurulu üyeliği işlevsizleştirilmiş olmaktadır. Buna karşılık kapsamı iyi tayin edilmezse bir şirkette gerçekleştirilen bütün usulsüzlüklerden üye ler sorumlu tutulur. Bu yönde bkz. KIRCA / ŞEHİRALİ ÇELIK / MANAVGAT, s. 615.

74 KIRCA / ŞEHIRALİ ÇELIK / MANAVGAT, s. 614.

75 KOÇ, S. 86.

76 KIRCA / ŞEHİRALİ ÇELIK / MANAVGAT, s. 614.

77 PULAŞLI, Genel Esaslar, s. 412. 
aktif bir bilgi akışıyla mümkündür ${ }^{78}$. Yönetim kurulu ancak bu durumda üst gözetim yükümlülüğünü gereği gibi ifa edebilir. Özellikle bu noktada iç yönerge devreye girmektedir. İç yönergede kimin kime bilgi sunmakla yükümlü olduğu önceden, yazılı ve açık bir biçimde belirlenmektedir. Dolayısıyla bilgi akışının ne yönde ve nasıl gerçekleşeceği bu şekilde kesinlik kazanmaktadır. Bir başka ifadeyle, aynı bir zincirin halkaları gibi birbirine bağlı şekilde, yönetim kurulunun üst gözetim yükümlülüğünün gereği gibi yerine getirebilmesi bilgi akışının etkinliğine, bu bilgi akışının etkinliği de iç yönergenin detaylı ve kapsamlı olarak düzenlenmesine bağlıdır. Söz gelimi kimin kime bağlı ve birbirine bilgi sunmakla yükümlü olduğunun belirtildiği bir iç yönergenin düzenlenmemesi durumunda adeta bir kaos oluşacak ve bu durum hem yönetim kurulunun hem de yetkinin devredildiği kişilerin yükümlülüklerini yerine getirememesi sonucunu doğuracaktır. Bu açıdan şunu da eklemek isteriz ki, üst gözetim yükümlülüğünün sorumluluktan kurtarma etkisini zayıflatmasını bir nebze azaltmak için iç yönergede yetkilerin kapsamına ve sınırlarına ilişkin düzenlemeler yapılabilir. Örneğin kimin kime bilgi sunmakla yükümlü olduğu hususunda iç yönergede çok net ve detaylı bir hüküm öngörülebilir. Bu kapsamda yapılan bir düzenleme aradaki bilgi akışının yoğunluğunu artıracak ve üst gözetim görevinin gereği gibi yerine getirilebilmesine zemin hazırlayacaktır. Nihayetinde etkin bir üst gözetim olması halinde üst gözetim gerekçe gösterilerek kurul üyelerinin sorumluluğuna gidilmesi ihtimali azalacaktır.

Küçük ölçekli anonim şirketlerde yönetim kurulu üyelerinin sayıca az olması veya şirketlerin iş ve işlemleri ile ilgilenen kişilerin sayısının da buna paralel olarak sınırlı olması nedeniyle üst gözetimsorumlur luğu hususunun nispeten daha az gündeme geldiği kanaatindeyiz. Ancak büyük ölçekli anonim şirketlerde yönetim kurulu üye sayısı fazla olduğundan ve şirketi ilgilendiren iş ve işlemlerin sayısının çok olması nedeniyle yönetim ve temsil faaliyêlerinin aksamaması için yardımcı kişilere ihtiyaç duyulmaktadır ${ }^{79}$. Bu ihtiyaç esasen şirketin daha profesyonel kişilerce yönetilmesinin istenmesinden de kaynakJanabilir. Bu doğrultuda kanun koyucu, yukarıda ayrıntısına değinildiği üzere, yönetim kurulunun sahip olduğu temsil yetkisinin de belirli koşullar altında devrine olanak tanımıştır. Dolayısıyla yönetim yetkisinin devri mümkün olduğu gibi temsil yetkisinin devri de -yukarıda değinilen koşullar dâhilinde- mümkündür. Söz konusu şirketlerde belirtilen nedenlerle birden çok kişiye yönetim ve temsil yetkisi verilebilmekte, hatta yetki devri daha çok profesyonellere yapılmaktadır. Bu kapsamdaki şirketlerde elbette üst gözetim yükümlülügünün ve buna bağlı sorumluluğun daha fazla gündeme gelebileceği ifade edilebilir.

TTK'nın 370'inci maddesinin 2'nci fikrasında temsil yetkisinin devredilebileceği hüküm altına alınmıştır. Düzenlemeye göre yönetim kurulu üyelerinin tümünün temsil yetkisini üçüncü kişilere devretmesi mümkün değildir. Bu kapsamda en az bir üyenin temsil yetkisine sahip olmasi esastır. Hükmün gerekçesine ${ }^{80}$ bakıldığında bu düzenlemeyle ulaşılmak istenenin 367/1 hükmü dolayısıyla yönetim yetkisi ile birlikte temsil yetkisini de devredilebilir hale getirmek olduğu görülmektedir. $\mathrm{Bu}$ bağlamda TTK'nın 370/2 ve 367/1'inci maddeleri birlikte dikkate alınmalıdır ${ }^{81}$. Gerçekten de yönetim yetkisinin, başka bir deyişle şirketin işletme konusunu gerçekleştirmeye yönelik karar alma yetkisinin tek başına devi bir anlam ifade etmeyecektir. Burada belirtmek gerekir ki, sadece yönetimin devrini ya da sadece temsile yönelik yetkilerin devrini içeren iç yönerge hazırlanması da söz konusu olabilir ${ }^{82}$. Ancak yönetim ve temsil yetkileri birbiri ile çok yakın bağlantı içerisinde olduğundan ve yönetim ile temsil yetkilerinin ayrılması durumunda ayrılan yetkilerin kullanılması sırasında hukuki problemler oluşma riski göz önüne

78 KIRCA / ŞEHIRALİ ÇELIK / MANAVGAT, s. 614, 562. Burada bahsolunan bilgi akışı, salt yönetimle görevli kişilerin yönetim kuruluna vereceği bilgileri değil, yönetim kurulunun şüphe duyduğu hususlar hakkında bilgi talep etmesini de kapsamaktadır.

79 BALABAN, s. 52.

80 Bkz. TTK 370 Madde Gerekçesi: “Birinci fikra: 370'inci maddenin birinci fikrasl, 365 'inci maddede yer alan şirketin temsili yetkisinin, aksi șart edilmemișse, yani tek imza sistemi kabul olunmamıșsa, çift imza ile ve yönetim kurulunca kullanılabileceğini öngörmektedir. 373 'üncü maddenin birinci fikrası hükmünce yönetim kurulu şirketi temsile, yetkili kişileri de belirler. İkinci fikra: İkinci fikra, 6762 sayılı Kanun 319 'uncu maddesinin ikinci fikrası hükmünü tekrarlayarak, 370'inci madde dolaylstyla devredilebilen yönetim hakknı temsil yetkisi ile tamamlamak amacıyla öngörülmüştür."

81 KIRCA / ŞEHIRALİ ÇELIK / MANAVGAT, s. 594; KUTLUK, Tansı: Anonim Şirketlerde Yönetim ve İç Yönerge Hazırlanması, Seçkin Yayıncılık, Ankara, 2020, s. 80.

82 BAHTiYAR, Mehmet: “Anonim Ortaklıkta Yönetim ve Temsil Yetkisinin Kullanılması ve Devri”, Prof. Dr. Haluk Burcuoğlu'na Armağan, Cilt 1, Filiz Kitabevi, İstanbul, 2020, s. 327. 
alındığında hem yönetim hem de temsilin devrini içeren tek bir iç yönerge hazırlanmasının daha uygun olacağı kanaatindeyiz ${ }^{83}$. Yetkiyi devralan alınan kararlar doğrultusunda temsil yetkisini kullanarak işlem yaptı̆g t takdirde hüküm tam anlamıyla amacına ulaşacaktır. Örnek olarak, kendisine yetki devri yapılan kişinin üçüncü bir kişiyle bir satım sözleşmesi akdetmesi verilebilir.

Şirket esas sözleşmesinde yönetim kurulunun yetki devri yapması için açık bir hüküm bulunması gerektiğine yukarıda işaret edilmişti. Zira yönetim yetkisinin devrinde buna izin veren bir esas sözleşme hükmü aranmaktayken, etkisi bakımından yönetimin devrinden daha bağlayıcı sonuçlar doğurabilecek temsil yetkisinin devrinde böyle bir hükmün varlığına evleviyetle (argumentum a fortiori) ihtiyaç bulunduğu kanaatindeyiz.

TTK m 370/2 düzenlemesi uyarınca yönetim kurulu, uygun gördüğ̈̈ takdirde temsil yetkisini devrettiği kişilerden geri alabilmektedir. Bu azil yetkisi TTK 375/1 hükmünün (d) bendine dayanmakta olup devredilemez ve vazgeçilemez nitelik taşır. Nihayetinde kendisine temsil yetkisi devredilen murahhaslar organ sıfatını iktisap ederek şirketi üçüncü kişiler nezdinde hak ve borç sahibi yapabilmektedir². Bu sebeple bu kişiler de TTK 369 ve 553'üncü maddeleri kapsamında yönetim kurulu üyeleri ile aynı sorumluluk rejimine tabi olacaklardır ${ }^{85}$. Gerçekten de kendisine yetki devri yapılan murahhaslara bu şekilde bir sorumluluk atfedilmiştir. Aksi durumda yetki devrinin bir anlamı olmayacak, sorumluluk kurul üyelerinde kalmaya devam edecektir. Oysa yukarıda da belirttiğimiz üzere yetki devri, sorumluluktan kurtarmak gibi bir ana hedefe yönelmektedir. Bu açıdan yetkiyi devralanların sorumlulukları TTK'nın 553' üncü maddesine göre bel irlenmektedir. Y etkinin murahhaslara devri durumunda da yönetim kurulu açısından yukarıda değindiğimiz özen yükümlülüğü devam etmektedir. Zira üst gözetim görevi özen yükümlülüğüyle sıkı bir bağlılık içerisinde olduğundan ve ayrıca TTK'nın 375'inci maddesinde devredilemez ve vazgeçilemez yetkiler arasında sayıldığından talimat verme ve gözetimde gerekli özenin gösterilmesi konusunda yönetim kurulunun sorumluluğu devam edecektir ${ }^{86}$.

Yönetim kurulu temsil yetkisi olmayan üyeleri ve/veya şirket çalışanı olan profesyonelleri temsilci olarak atayabilir ${ }^{87}$. İşte çalışmamızın odak noktasını oluşturan iç yönerge düzenlenmesinin bir zorunluluk olarak gündeme geldiği diğer bir nokta burada karşımıza çıkmaktadır ${ }^{88}$. Söz konusu atamanın gerçekleşebilmesi için TTK'nın 367'nci maddesi uyarınca yönetim kurulu tarafından hazırlanan iç yönergede atamaya ilişkin bir hükmün yer alması yeterlidir. İç yönergede böyle bir hükme yer verildikten sonra yönetim kurulu tarafindan atanmayı ihtiva eden bir kurul kararı almasını müteakip bu kararın TTK m. 371/7 hükmü uyarınca tescil ve ilan edilmesi gerekli ve yeterli olacaktır.

Genel olarak bu kapsamda yönetim kurulunun bir iç yönerge ile temsil yetkisini murahhaslara devrettiği durumda yetki verilmeyen üyeler "icra yetkisi olmayan üye (non-executive director)" haline gelmekte ve bu nedenle sınırlı olarak dahi bu kişilerin anonim şirketi dışa karşı temsil etme yetkileri bulunmamaktadır. TTK m. 371/7 hükmüyle temsil yetkisini haiz olmayan üyelere temsil yetkisi verilmesi sağlanarak icra yetkisi olmayan yönetim kurulu üyelerinden faydalanma yoluna gidilmiştir ${ }^{89}$. Buna ilave olarak temsil yetkisinin devrinin iç yönerge ile yapılması ve iç yönergenin tescil ve ilan edilmesi neticesinde atama işlemine aleniyet kazandırılmış olup böylece, yukarıda da ifade ettiğimiz gibi, gündeme gelmesi muhtemel yetkisiz temsilci tartışmalarının önüne geçilmek istenmiştir.

83 KUTLUK, S. 81.

84 KIRCA / ŞEHIRALİ ÇELIK / MANAVGAT, s. 629.

85 BALABAN, s. 52.

86 KIRCA / SSEHIRALİ ÇELIK / MANAVGAT, s. 616.

87 TTK 371 hükmüne 10.09.2014 tarihinde 6552 sayılı Kanun'la 7. fikra eklenmiștir. TTK m 371/7 hükmüne göre “Yönetim kurulu, yukarıda belirtilen temsilciler dışında, temsile yetkili olmayan yönetim kurulu üyelerini veya şirkete hizmet akdi ile bağlı olanları sinırlı yetkiye sahip ticari vekil veya diğer tacir yardımcıları olarak atayabilir. Bu şekilde atanacak olanların görev ve yetkileri, 367 'nci maddeye göre hazırlanacak iç yönergede açıkça belirlenir. Bu durumda iç yönergenin tescil ve ilanı zorunludur. İ̧̧ yönerge ile ticari vekil ve diğer tacir yardımclları atanamaz. Bu fikra uyarınca yetkilendirilen ticari vekil veya diğer tacir yardımcılarl da ticaret siciline tescil ve ilan edilir. Bu kişilerin, șirkete ve üçüncü kişilere verecekleri her tür zarardan dolayl yönetim kurulu müteselsilen sorumludur.". Bu hüküm doğrultusunda hazırlanan iç yönerge “Temsile İlişkin Yönetim Kurulu İç Yönergesi” olarak adlandırılmaktadır. 


\section{6552 SAYILI KANUN İLE YAPILAN DEĞİŞIKLIKLLER}

6552 sayılı Kanun'un 131'inci maddesi ile TTK m. 371 düzenlemesine 7'nci fikra hükmü eklenmiştir. 6552 sayılı Kanun ile yapılan yeni düzenleme neticesinde yönetim kurulunun temsil yetkisine sahip olduğu kuralı ile bu yetkinin belli şartlarda yönetim kurulu üyeleri ve/veya üçüncü kişilere devredilebilmesi usulü korunmuştur. Esasında bu ekleme ile yönetim kurulunda var olan temsil ve yönetim yetkilerinin korunmasının yanında, uygulamada özellikle temsille ilgili konularda ortaya çıkan talepleri karşılamak amacıyla mehaz kanunda olmayan yeni hükümler getirilmiştir ${ }^{90}$. Ancak söz konur su düzenlemede yönetim kurulunun yetki devri yapılmış olsa da sorumluluğunun devam ettiği, hatta müteselsil sorumluluğun söz konusu olduğu yönünde bir düzenleme getirilmesi TTK'nın yetki devri ve sorumluluk ilkeleri ile çelişmektedir. Bu nedenle söz konusu düzenlemenin yerinde olmadığı ifade edilebilir. Doktrinde de genel olarak söz konusu değişikliğin hiç yapılmamış olmasının hukuki açıdan daha yerinde olacağı belirtilmektedir ${ }^{91}$. Bizce de bu düzenleme ile en azından sorumluluk açısından TTK'nın ruhuna ve amacına uygun olmayan bir yaklaşımla "yönetim kurulunun müteselsil sorumluluğu" kavramı hukukumuza tekrar getirilerek kanun sistematiğinin bozulmasına neden olunmuştur.

Anonim şirket yönetim kurulu prensip itibariyle birlikte hareket ederek yönetim görevini yerine getirir ve şirketi üçüncü kişiler nezdinde temsil eder. Bunu yaparken yönetim kurulu kusurlu eylemleri ile açıkça bir şirket zararına sebebiyet verebilir. Bu anlamda, yukarıda ayrıntısına değindiğimiz gibi, TTK'nın 553'üncü maddesinde yönetim kurulunun sorumluluğuna ilişkin hükümler gündeme gelecektir. Bu maddleye göre bir yönetim kurul u üyesinin veya yetkiyi devralan yöneticinin sorumlu olabilmesi için zararla ilgili açıcça kusurlu olması ve bu kusurun da ispat edilebilmiş olması gerekir. Buna karşın 6762 sayılı mülga TTK'ya göre yönetim kurulu üyeleri "kusursuzluklarını ispatlamadıkça" zarardan sorumlu tutulmaktaydı. 6102 sayılı TTK ile bu yaklaşımdan isabetli olarak vazgeçilerek daha hakkaniyetli bir sistem benimsenmiştir. Bunun yanında 6762 sayılı mülga TTK ile yönetim kurulu üyeleri için genel olarak müteselsil sorumluluk hali kabul edilmekteyken, 6102 sayılı Kanun ile isabetli bir şekilde müteselsil sorumluluk halinden vazgeçilerek yönetim kurulu için "farklılaştırılmış teselsül" ilkesi kabul edilmiştir. Artık bu yeni sistem ile meydana gelen zararlarla ilgili her bir yöneticinin kusurları oranında sorumluluğu gündeme gelmektedir. Oysaki 6762 sayılı mülga TTK'da yer verilmiş olan "mutlak teselsül" sisteminde zararlı sonucun oluşmasına hafif kusuruyla sebep olsa dahi zararın tamamı ilgili üyeden tazmin edilebilmekte, sonrasında ise ilgili üyenin rücu hakkını kullanamadığı durumlarda hakkaniyete aykırı sonuçlar ortaya çıkmaktaydı.

6102 sayılı TTK'da da yönetim kurulu üyelerinin sorumluluğu kusur sorumluluğu esası üzerine inşa edilmiştir. 6552 sayılı Kanun ile TTK'nın 371'inci maddesine 7'nci fikranın eklenmesi ile TTK'da benimsenen sisteme ters düşen bir düzenleme getirilmiştir. Öyle ki yeni getirilen düzenleme ile “her türlü zarardan" bahsedilmekteyse de burada TTK'nın 553'üncü madde hükmü dikkate alınd1ğında kusursuz bir şekilde söz konusu olan zararlardan dolayı sorumluluğun doğması mümkün olmamalıdır ${ }^{92}$. Zira bir kişinin açıkça kusuru bulunmadığ 1 durumlarda yetkiyi bir başka üçüncü kişiye devrettiği hallerde kendisi sorumlu tutulamazken kendisini atayan yönetim kurulu üyelerinin sorumlu olmasının evleviyetle (argumentum a fortiori) mümkün olmaması gerekir. Şirkette temsil yetkisini, usulüne göre yapılmış bir iç yönerge ile devreden yönetim kurulu üyesinin/üyelerinin, hiçbir açık kusuru bulunmadan, yetkiyi devralan bir başka üyenin/kişinin kusuru ile meydana gelen zarardan dolay1 sorumlu tutulmaları TTK m. 553 hükmüne aykırılık teşkil eder. Kanaatimizce yönetim kurulu, usulüne uygun olarak çıkarılmış bir iç yönerge ile yönetim ve/veya temsil yetkisini kurul üyeleri içinde bir veya birkaç üyeye veya kurul üyesi olmayan üçüncü kişilere devretmiş ve bu devirde gerekli makul

90 ÖZDAMAR, Mehmet: “6552 Sayılı Kanun ile TTK'da Yapılan Değișiklikler Cerçevesinde Anonim Sirketin Temsili”, Gazi Üniversitesi Hukuk Fakültesi Dergisi, 2014, Cilt 18, Sayı 3, s. 153.

91 KIRCA, İsmail: “TTK m. 371/7 Hakkında Bir İnceleme: AB’ye Üyelik Yolunda Geri Adım”, Banka ve Ticaret Dergisi, 2014, Cilt 30, Sayı 3, s. $21 \mathrm{vd}$

92 ÖZDAMAR, s. 161. 
özeni göstermiş ise artık yetkiyi iç yönerge ile devralan kişilerin kusurlarından kaynaklanan şirket zararlarından sorumlu tutulmaması gerekir. Her ne kadar TTK m. 371/7 hükmü bu konuda kanaatimizin aksi yönünde yorumlanabilse de sorumluluk şartlarını belirten ana düzenleme olan TTK 553'üncü maddenin açık lafzı, bu maddenin gerekçesi, 369, 370, 371' inci maddeler ve bu maddelerin gerekçeleri birlikte değerlendirildiğinde söz konusu 371/7 düzenlemesinin işaret ettiğimiz şekilde yorumlanma sının yerinde olacağı kanaatindeyiz. Dolayısıyla bu hususta sorumluluk tayin edilirken TTK'nın 553' üncü maddesi hükmünün dikkate alınması gerektiğini değerlendirmekteyiz. Bunun yanında TTK m 371/7' deki düzenlemenin “müteselsil sorumluluk” kısmının kaldırılarak, düzenlemedeki sorumluluk ifadesinin 553' üncü madde ile uyumlu hal e getirilmesi yerinde ol acaktır.

\section{SONUÇ}

Anonim şirketlerde yetki devrinin yapılabilmesi için esas sözleşme ile buna izin verilmiş olması ve bu kapsamda usulüne uygun olarak onaylanmış bir iç yönergenin varlığı gerekir. Ancak yönetim kurulunun her yetkiyi devredebilmesi mümkün değildir. Bu kapsamda yönetim kurulunun devredilemez ve vazgeçilemez yetkileri (TTK m 375) yetki devrinin sınırını oluşturur. Yönetim kurulunun yetkilerini iç yönergeye göre devrederken devrin kapsamının da TTK 375 'inci madde hükmünde sayılan hususları ihtiva etmemesi gerekmektedir. Ancak bunun yanında yönetim kurulu yetki devri yaparken yetkiyi devralacak kişilerin seçiminde gerekli özeni göstermeli ve yetki devri yaptıktan sonra yetkiyi devralan temsilcileri makul ölçülerde gözetmelidir. Çünkü yönetim kurulunun gözetim yetkisi devredilemez ve vazgeçilemez yetkileri arasında sayılmıştır. Bu kapsamda şirketin yönetim ve temsil yetkisinin devri TTK'nın 367'nci maddesinde belirtilen usule göre çıkartılacak bir iç yönerge ile mümkün olmaktadır. Esasında iç yönerge ile hem 367' nci maddeye göre yönetim yetkisi devredilebilirken hem de 371'inci maddeye göre temsil yetkisi devredilebilmektedir. Bu yetki devrinin temel amaçlarından biri de yetkisiz yönetim kurulu üyelerinin sorumluluktan kurtulmasıdır. Ancak 371'inci maddeye 6552 say1lı torba kanun ile bir ekleme yapılarak bu amaç sekteye uğratılmıştır.

TTK'da 6552 sayılı Kanun ile yapılan değişiklikle birlikte iç yönerge ile yapılan temsil yetkisinin devri sonucunda yetkileri devralan kişilerin kusurlu davranışlarından dolayı sorumluluğunun tayini hususu TTK'nın konu ile ilgili diğer düzenlemeleri ile çelişir hale gelmiştir. TTK'nın 553/2 hükmünde açıkça görüleceği üzere yönetim kurulunun sahip olduğu yetkiyi kanunun kendisine izin verdiği şekilde devretmesi durumunda artık yönetim kurulunun sorumluluğundan bahsetmemek gerekmektedir. Nitekim iç yönerge düzenlenmesi suretiyle yapılacak yetki devrinin bir amacı da bu şekilde yetkisiz yönetim kurulu üyesini sorumluluktan kurtarmaktır. Kanun koyucu vardığımız bu sonucu TTK'nın 553/3 hükmü ile desteklemektedir. Yönetim kurulunun yönetim ve temsil görevinin dışında ayrıca gözetim yükümlülüğünün de bulunduğunun kabulü ile birlikte yetki devri halinde yalnızca işbu gözetimyükümlülüğünün bulunduğu ileri sürülerek sorumluluğun gündeme getirilebilmesi mümkün olmamalıdır.

Kanaatimizce TTK m 371/7'deki hüküm istisnai nitelikte olup bunun dar yoruma tabi tutulmas1 gerekmektedir. Dolayısıyla usulüne uygun bir iç yönerge ile yapılan yetki devri sonucunda yetkiyi devralan kişilerin kusurları ile meydana gelen şirket zararları sonucunda sorumluluklar belirlenirken 553' üncü madde uygul anmaya devam edil Imelidir. Bu kapsamda bir kere daha önemle bel irtmek isteriz ki, getirilen yeni düzenleme TTK'nın gerek sistematiğine gerekse benimsediği temel sorumluluk prensiplerine aykırılık taşımaktadır. Ancak halihazırda getirilen bu emredici düzenlemenin nazara alınmaması hukuken mümkün değildir. Ancak hüküm dar yoruma tabi tutularak yalnızca yönetim kurulunun kanunda düzenlenen şekilde ticari yardımcı ve vekil ataması halinde gündeme gelerek sorumlulukların belirlenmesinde göz önüne alınması söz konusu çelişkili durumu bir nebze de olsa orta dan kaldırabilecektir. Aksini kabul etmek, sorumluluk esasını düzenleyen bütün maddelerin uygulanmasını güç ve hatta imkânsız kılacaktır. Ancak TTK m. 371/7'deki düzenlemenin bu şekilde yalnızca belirli kişilere yapılacak yetki devrinde söz konusu olması da sorunu çözmeye yeterli olmayacaktır. Bu nedenle kanaatimizce ilgili düzenlemenin Kanun'dan çıkartılması veya konunun TTK'nın 553'üncü maddesi ile uyumlu şekilde tekrar kaleme alınması bizce bir zorunluluktur. 


\section{KAYNAKÇA}

AKDAĞ GÜNEY, Necla, “6552 Sayılı Torba Kanun ile TTK md. 371'e Eklenen Yedinci Fıkraya İlişkin Değerlendirmeler" (6552 Sayılı Torba Kanun), (http://www.arslanlibilimarsivi.com/node/25, E.T.: 14.03.2021).

AKDAĞ GÜNEY, Necla: Anonim Şirket Yönetim Kurulu, 2. Bask1, Vedat Kitapçıllk, İstanbul, 2016 (Yönetim Kurulu).

AKSOY, Mehmet Ali: "Türk Kurumsal Yönetim Düzenlemeleri Kapsamında Anonim Şirket Yönetim Kurulu”, Gazi Üniversitesi Hukuk Fakültesi Dergisi, 2013, Cilt 17, Sayı 1-2, s. 45-76.

AYHAN, Rıza / ÇAĞLAR, Hayrettin / ÖZDAMAR, Mehmet: Şirketler Hukuku Genel Esaslar, 3. Baskı, Yetkin Yayınları, Ankara, 2021.

BAHTIYAR, Mehmet: Ortaklıklar Hukuku, 15. Baskı, Beta Yayınevi, İstanbul, 2021 (Ortaklıklar Hukuku).

BAHTIYAR, Mehmet: “Anonim Ortaklıkta Yönetim ve Temsil Yetkisinin Kullanılması ve Devri”, Prof. Dr. Haluk Burcuoğlu’na Armağan, Cilt 1, Filiz Kitabevi, İstanbul, 2020.

BALABAN, Mahmut Furkan: Anonim Şirket Yönetim Kurulu Üyelerinin Hukuki Sorumluluğu ve Sorumluluk Davası, Ufuk Üniversitesi Sosyal Bilimler Enstitüsü, Ankara, 2019.

CEYLAN, Nurgün: “Anonim Şirketlerde Yönetim ve Temsil Yetkisinin Devrinin Anlamı, Sonuçları ve TTK m. 371 f. 7 ile Karşılaştırılması", Türkiye Noterler Birliği Hukuk Dergisi, 2015, Cilt 2, Sayı 1, s. 21-38.

DEMIREL, Duygu: “Anonim Şirketlerde Yönetim Yetkisinin Devri”, Hacettepe Hukuk Fakültesi Dergisi, 2017, Cilt 7, Say1 2, s. 214-250.

ERIŞ, Gönen: Anonim Şirketler Hukuku, 1. Bask1, Seçkin Yayıncılık, Ankara, 1995.

HELVACI, Mehmet: "Yönetim Kurulunun Anonim Şirketi İdare ve Temsili, Özellikle Devredilemez Görev ve Yetkileri", Bahçeşehir Üniversitesi Hukuk Fakültesi Dergisi, 2014, Cilt 9, Sayı 117-118, s. 119-132.

KAPLAN, İbrahim: “6102 sayılı YTTK Hükümlerine Göre Şirket Yönetim Kurulu Üyeleri ve Diğer Üst Yöneticilerin, Şirkete, Ortaklara ve Şirket Alacaklılarına Karşı Hukuki Sorumluluğu”, Ankara Üniversitesi Hukuk Fakültesi Dergisi, 2016, Sayı 65, s. 3493-3509.

KILIÇOĞLU, Ahmet: Borçlar Hukuku Genel Hükümler, 25. Basım, Turhan Kitabevi, Ankara, 2021.

KIRCA, İsmail: “TTK m 371/7 Hakkında Bir İnceleme: AB'ye Üyelik Yolunda Geri Adım”, Banka ve Ticaret Hukuku Dergisi, 2014, Cilt 1, Sayı 3, s. 23-37.

KOÇ, Himmet: “Anonim Şirketlerde İç Yönerge ve İç Yönergenin Benzer Hukuki Kurumlarla Olan İlişsisi”, Medeniyet ve Toplum, 2017, Cilt 1, Sayı 2, s. 163-186 (İç Yönerge).

KOÇ, Himmet: Anonim Şirketlerde İç Yönerge ile Yönetim ve Temsil Yetkisinin Devri, Gazi Üniversitesi Sosyal Bilimler Enstitüsü, Ankara, 2017.

KUTGİ TAŞAN, Ayșe Selcen: Anonim Şirketlerde Temsil Yetkisinin Yönetim Kurulu Tarafindan Kullanılması, İstanbul Ticaret Üniversitesi Sosyal Bilimler Enstitüsü, İstanbul, 2019.

KUTLUK, Tansı: Anonim Şirketlerde Yönetim ve İ̧̧ Yönerge Hazırlanması, Seçkin Yayıncılık, Ankara, 2020.

MANAVGAT, Çağlar / ŞEHIRALİ ÇELIK, Feyzan Hayal / KIRCA, İsmail: Anonim Şirketler Hukuku, Cilt 1, Banka ve Ticaret Hukuku Araştırma Enstitüsü Yayınları, Ankara, 2013.

OĞUZ, Habip: “Sorumluluk Hukukunda Kusur”, Türkiye Adalet Akademisi Dergisi, 2016, Say1 28, s. 273-286.

OKTAY KILIÇ, Duygu: Anonim Şirketlerde Yönetim Kurulu Üyelerinin Hukuki Sorumluluğu, DicleÜniversitesi Sosyal Bilimler Enstitüsü, Diyarbakır, 2016.

ORAN, Ozan: Anonim Şirketlerde Yönetim Kurulu İ̧̧ Yönergesi, İstanbul Üniversitesi Sosyal Bilimler Enstitüsü, İstanbul, 2019.

ÖZDAMAR, Mehmet, "6552 Sayılı Kanun ile TTK'da Yapılan Değişiklikler Çerçevesinde Anonim Şirketin Temsili", Gazi Üniversitesi Hukuk Fakültesi Dergisi, 2014, Cilt 18, s. 137-164. 
ÖZER, Akif: "İşletmelerde Stratejinin Önemi Üzerine Değerlendirmeler", Uluslararası İktisadi ve İdari İncelemeler Dergisi, 2015, Sayı 14, s. 69-84.

ÖZKORKUT, Korkut: Anonim Ortaklıklarda Yönetim Kurulu Kararlarının İtali, Sermaye Piyasası Kurulu Yayınları, Ankara, 1996.

POROY, Reha / TEKINALP, Ünal / ÇAMOĞLU, Ersin: Ortaklıklar Hukuku I, 14. Baskı, Vedat Kitapçıllk, İstanbul, 2019.

PULAŞLI, Hasan: Şirketler Hukuku Genel Esaslar, 7. Baskı, Adalet Yayınevi, Ankara, 2021 (Genel Esaslar).

PULAŞLI, Hasan: Şirketler Hukuku Şerhi, Cilt 2, 3. Baskı, Adalet Yayınevi, Ankara, 2018 (Şerh).

ŞENER, Oruç Hami: Ortaklıklar Hukuku Ders Kitabı, 4. Baskı, Seçkin Yayıncılık, Ankara, 2019.

TEKİNALP, Ünal: Sermaye Ortaklıklarının Yeni Hukuku, 4. Baskı, Vedat Kitapçılık, İstanbul, 2015. 